\title{
Illocutionary act between barista and customers in starbucks coffee shop at Changi airport
}

\author{
Isbandi $^{1}$, Nurma Dhona Handayani ${ }^{2}$ \\ 1,2English Department, Putera Batam University, Indonesia \\ 1isbandi.ben@yahoo.com, ${ }^{2}$ nurmadhona@gmail.com \\ *) correspondence: isbandi.ben@yahoo.com
}

\begin{abstract}
This research primarily aimed to analyze the types of the illocutionary act proposed by Searle (1979), secondly to find the dominant type produced by both sides, between barista and customers' utterances at Starbucks coffee shop Changi Airport. This research applied observational method and nonparticipatory technique as the way collecting the data. The design of this research were qualitative and quantitative research. Qualitative research is applied to analyze the data in the form text. In contrast, quantitative research used to count the number of utterances, to conclude which types of illocutionary acts find dominantly during the conversation. It was found that directive, representative, and expressive types were in the utterances. Meanwhile, commissive and declaration type did not find in the utterances. The result from this study showed that directives illocutionary act as the most frequently found in utterances, because the communication which takes place in coffee shop between the baristas and customers usually only needed to ordering and just give information (informing).

Key words: pragmatic; speech act; illocutionary act
\end{abstract}

\section{INTRODUCTION}

In this world, language is an essential tool in communication for a human being, it is used to communicate each other; either to give information, to express their feelings or to ask questions. Every single situation in our life usually communication is needed because basically, humans are social being who need language to communicate. In other words, language is a media to deliver our willingness, ideas, and feelings.

At the same time, when the communication occurs, the elements like context, when, where, and to whom people speak with, will affect the way they communicate. For instance, when someone talk to his friends definitely he will act differently or bring out different utterance when he communicates to his teacher. It means that in the reality, people will have produced formal or polite utterance when they communicate with people in different level. Different level here can be formed due to several factors, such as differences in age, gender, profession or also due to social status factors.

For that reason, it is not easy to understand the meaning language that is used by people in communication. It is because people attend to act differently and their utterance will depend on the context and to whom speak with. Those acts which are created by the people while they are speaking is called speech act. According to Yule (1996), speech act is an act in saying something. Besides, Austin (1962) stated that there are three levels of speech act, such as locutionary act, illocutionary act and perlocutionary act.

The first type of speech act called locutionary, the locutionary act means that hearer analyze what is the natural meaning the utterance from the speaker had produced, it can be ordering, asking or informing, after that the second type of speech act called illocutionary, in this step the hearer analyzed the act and also the expression from the speaker when they generate an utterance. The last type of speech act called Perlocutionary, this is the step where act performed by or as a result on the hearer of what the speaker says.

Related to explanation above, this research would be focus on the analysis of Illocutionary found in utterances between barista and costumers in the Starbucks Coffee shop at Changi Airport. First, 
find out types of illocutionary acts and the second to identify which types of illocutionary acts frequently used in the conversation between the barista and their customers.

In conducting this research, the researchers were interest to analyze illocutionary act during conversation between barista and customers in Starbucks coffee shop at Changi Airport Singapore. The researchers chose this place as the object of the research; the first because it is known that Starbucks is one of the most famous coffee shop in the world and the second reason is also known that airport is the place where people want to go for travelling, there are so many people from around the world will do travelling or just stop by, thus the researchers would get various of data in this study.

There were several researches that have analyzed about Illocutionary Act such as in the case of analysis and classification of direction in written advertisement by Simon \& Cartis (2015). They focused on directives of illocutionary act only, this study found that there were four types of direction that were given to the receiver of the advertisement (imperative, interrogative, appellative and indirect appellative direction).

Similarly, in drama script also has its own type of speech acts. This analysis have been done by Yuniati (2013). She conducted the qualitative research to find out expressive illocutionary act identified in The Newly Married Couple drama script. Her analysis concluded that there are six types of expressive illocutionary act such as congratulating, thanking, apologizing, welcoming, wishing and attitude.

\section{Pragmatics}

Pragmatics is a study of relationship between linguistic forms and the users of those forms; that is, words that literally connect to what the user of those words intended to convey. According to Cutting (2002) stated that Pragmatics examines the meaning externally. It means that Pragmatics is the studies of speakers meaning. In Pragmatics humans are enable to do analysis, who can produce and understand the words. The interpretation is taking place while the speaker releasing or understanding the word, based the context, background as well as the relation between the users of those words.

\section{Speech act}

When constructs the communication people regularly produced an act and that act known as speech act. This speech act developed by John Searle (1969) which the theory firstly created by Austin (1962). (Yule, 1996) states that the act include in speech act such: "inform", "request", "command", and "questioning". More explanation towards this speech act, he gives some examples that can be seen in this table below:

\begin{tabular}{cc}
\hline Forms & Function \\
\hline Did you eat the food? & Question \\
Eat the food (please). & Command (Request) \\
You ate the food. & Statement \\
\hline
\end{tabular}

Furthermore, (Yule, 1996) divided this speech act into two categories, direct speech act and indirect speech act. Yule described that if the speaker produces the same meaning with the form of its utterances it called direct speech act, meanwhile if the meaning of an utterances that established by the speaker different with its form of utterances it known as indirect speech act.

Based from the descriptions above towards speech act, it can have concluded that speech act is the acting that generated by the speaker when their producing an utterance. Moreover, speech act also classified into two types namely as direct and indirect speech act; the speaker created direct speech act if the meaning of the utterance that their produced have the same form with their utterance structure; and then if the speaker produced an utterance different with their form of language structure, it means that they produced indirect speech act. 


\section{Illocutionary act}

When discussing further about this speech act study, we will get a deeper level called the illocutionary act. Illocutionary act is the act of saying, which is committed with intend of speaker by uttering sentences, such like give a question, statement, order, apologize and threatening. In accordance with explanation from (Searle, 1979), illocutionary act is the performance of a particular language function. He defines that illocutionary act is the core part of language function. Other explanation described by Austin (1975) he declared that illocutionary act as an utterance which has a certain (conventional) force. In other words, illocutionary act refers on what someone say something.

\section{Classification of illocutionary act}

1) Representative

According the explanation from Searle (1979) that the purpose of this class is to perform the speaker to something's being the case, to the truth of the expressed proposition. It describes states or events in the world such as an assertion, a description, statement, report and conclusion; for example: I like expresso coffee

2) Directive

This category of illocutionary shows in the fact that it is an attempt by the speaker to get action from the hearer. Moreover Searle (1979) stated that directives include some actions, such as commanding, requesting, inviting, forbidding, and suggesting; for example: Could you explain about that?

3) Commissive

In this part of "commissive" refers to an illocutionary act whose point is to commit the speaker to some future course of action like promising, offering, threatening, refusing, vowing, and volunteering. In other words, commissive is types of speech act, where the speaker commands themselves to do future action through their utterance; for example: I will come to your house tomorrow.

4) Expressive

Expressive illocutionary act incorporates the acts which the words are to express the psychological condition about a state of affairs specified in the proportional content. So, it refers to an act where the speakers express their feeling and attitude about something; it can be a statement of pleasure, pain, like, dislike, joy and sorrow; for example: I'm glad to be here!

5) Declaration

Based on the explanation from Searle (1979) "declaration" its successful performance brings about the correspondence between propositional content and reality, successful performance guarantees that the propositional content corresponds to the world. Refer to this point Yule (1996) simplified Searle's explanation by saying that declaration is a kind of speech act that could change the world through one utterance. The words or expression that can change the world such as "I bet", "I declare", "I resign", "I pronounce", etc. for example: I hereby pronounce you busband and wife.

\section{METHODS}

This research used qualitative and quantitative research. Firstly, qualitative research which is aimed to explain the data in the form text. In contrast, quantitative research to count the number of utterances used by the barista and their customers to conclude which types of illocutionary acts find dominantly during the conversation occur.

In collecting data, the researchers used non-participant observational method, which the researchers did not involve in the conversation, only used note taking technique. The data were collected based from real conversation between barista and customers in Starbucks at Changi Airport Singapore, when they are ordering drinks or foods. 


\section{FINDINGS AND DISCUSSION}

Totally the researcher used five conversations, because each of conversation consists of two interlocutors, consist of barista and customers, so here the researcher uses symbol (B) representing the barista and $(\mathrm{C})$ for the customer, and also because sometimes there are two customers who came at the same time (in this case the customer is a husband and wife) then the researcher uses (C1) for the first customer and (C2) as the second customer.

The researcher will display the entire conversations with table, which each table divided into 3 column (the speaker, utterances and type of the speech act) so it will easier to identified and get the classification from each utterances, all the conversation can be seen in following data.

TABLE 1. Conversation 1

\begin{tabular}{clc}
\hline Speaker & Utterances & $\begin{array}{c}\text { Type of } \\
\text { Speech Act }\end{array}$ \\
\hline B & Hi & expressive \\
directive \\
C1 & Can I have double shot coffee, and for her.. & directive \\
C2 & What is that the yellow drink? (pointing to the picture) & representative \\
B & That's mango smoothies & directive \\
C2 & Is that coffee? & representative \\
B & No mam. Just mango smoothies. & directive \\
C2 & Alright, I'll take that & directive \\
C1 & For me double shot espresso. & directive \\
B & Okay, anything else? & directive \\
C2 & I want chicken sandwich & directive \\
B & that's all? & representative \\
C1 & Yes & directive \\
B & Having here? & representative \\
C1 & Yeah & directive \\
B & Your name please? & representative \\
C1 & Sandro & representative \\
B & The total is $\$ 3070$ cents & representative \\
C1 & I pay by card & expressive \\
B & Thank you & expressive \\
C1 & Thank you & \\
& &
\end{tabular}

(Source: Research Data, 2019)

TABLE 2. Conversation 2

\begin{tabular}{clc}
\hline Speaker & \multicolumn{1}{c}{ Utterances } & $\begin{array}{c}\text { Type of } \\
\text { Speech Act }\end{array}$ \\
\hline B & Hi & $\begin{array}{c}\text { expressive } \\
\text { directive }\end{array}$ \\
C1 & Can I have double shot coffee, and for her.. & directive \\
C2 & What is that the yellow drink? (pointing to the picture) & $\begin{array}{c}\text { representative } \\
\text { directive }\end{array}$ \\
B & That's mango smoothies & representative \\
C2 & Is that coffee? & directive \\
B & No mam. Just mango smoothies. & directive \\
C2 & Alright, I'll take that & directive \\
C1 & For me double shot espresso. & directive \\
B & Okay, anything else? & directive \\
C2 & I want chicken sandwich & representative \\
B & that's all? & directive \\
C1 & Yes & representative \\
B & Having here? &
\end{tabular}

(Source: Research Data, 2019) 
TABLE 3. Conversation 3

\begin{tabular}{|c|c|c|}
\hline Speaker & Utterances & $\begin{array}{c}\text { Type of } \\
\text { Speech Act }\end{array}$ \\
\hline $\mathrm{C}$ & Hi, can I have Ristretto Bianco & directives \\
\hline B & That's serve for hot only. & representative \\
\hline $\mathrm{C}$ & Yes & representative \\
\hline B & What size? & directive \\
\hline $\mathrm{C}$ & Grande please, and I want one peanut butter cake. & directives \\
\hline $\mathrm{B}$ & For having here? & directive \\
\hline $\mathrm{C}$ & Yes. & representative \\
\hline $\mathrm{B}$ & $\$ 14,90$ cents & representative \\
\hline $\mathrm{C}$ & PayWave & representative \\
\hline B & Your name? & directive \\
\hline $\mathrm{C}$ & Ben & representative \\
\hline $\mathrm{B}$ & You want to use paper cup or mug? & directive \\
\hline $\mathrm{C}$ & Paper cup, thanks & directive \\
\hline
\end{tabular}

(Source: Research Data, 2019)

TABLE 4. Conversation 4

\begin{tabular}{|c|c|c|}
\hline Speaker & Utterances & $\begin{array}{c}\text { Type of } \\
\text { Speech Act }\end{array}$ \\
\hline B & Hi. & expressive \\
\hline $\mathrm{C}$ & I want to order that drink (pointing to the picture) & directives \\
\hline $\mathrm{B}$ & Mango smoothies? & representative \\
\hline $\mathrm{C}$ & Yes & representative \\
\hline $\mathrm{B}$ & Anything else? & directive \\
\hline $\mathrm{C}$ & The red one too (on the picture) & directive \\
\hline $\mathrm{B}$ & Okay, what size? & directive \\
\hline $\mathrm{C}$ & Grande & representative \\
\hline $\mathrm{B}$ & the total $\$ 12.70$ cents & representative \\
\hline $\mathrm{C}$ & (giving the money) & \\
\hline B & Your name? & directive \\
\hline $\mathrm{C}$ & Shakuka & representative \\
\hline B & Wait over there please. & directive \\
\hline $\mathrm{C}$ & Thank you & expressive \\
\hline
\end{tabular}

(Source: Research Data, 2019)

\section{TABLE 5. Conversation 5}

\begin{tabular}{clc}
\hline Speaker & \multicolumn{1}{c}{ Utterances } & $\begin{array}{c}\text { Type of } \\
\text { Speech Act }\end{array}$ \\
\hline B & Hi, welcome & $\begin{array}{c}\text { expressive } \\
\text { directive }\end{array}$ \\
C & $\begin{array}{l}\text { Hi, I want two banana cake and one black paper } \\
\text { chicken roll }\end{array}$ & directives \\
B & having here or take away? & $\begin{array}{c}\text { representative } \\
\text { directive }\end{array}$ \\
C & Take away & representative \\
B & Anything else for you? & directive \\
C & Nope & \\
B & So, 2 banana cake and 1 black paper chicken roll, the & representative \\
& total is \$20.80 cents. Pay by? & directive \\
C & PayWave & expressive \\
B & Thank you and wait at the corner please & Thanks
\end{tabular}

(Source: Research Data, 2019)

\section{Representative}

According to Searle (1979) assertive or representative is types of illocutionary act which expressed speaker's belief of something, as well as explanation from Yule (2010), he classified the verb like "statement of fact, assertion, conclusion and description. For instance, in the conversations above, when the barista asked some questions to their customers like the size of drink, the customers simply 
said "tall" or "grande" and after the barista asked them about their name, the customers immediately mention their name.

Same with the barista when they give some information regarding their product to the customer like the price of their drinks or mention the balance from the payment, as we can see in conversation \#3, the barista said "that's serve for hot only". Based on Searle theory, both customers and barista produced assertive or representatives' illocutionary act is informing.

\section{Directive}

Related to the Searle's theory that have explained in previous pages, directives illocutionary act is refers to what speaker needs (Searle, 1979). In other words, if the speaker wants the hearer to do something by their utterance the speaker produced directives illocutionary act, namely like ask, order, command, request, beg invite, advice, etc. As can be seen in most conversation the the customers ordering food and drinks to barista "two ice mocha", "double shot espresso" or "I want chicken sandwich" while the customers ordering something, they produced directives illocutionary act that is order.

As well as the utterances delivered by the barista to the customers, they also produced the utterance directives illocutionary, like "your name?", "what size?", "baving here or take away?" or "anything else?" those kind of questions that barista frequently ask to their customers are part of directive illocutionary act, in term of ask.

\section{Expressive}

Be in accordance with Searle's theory, expressive is types of illocutionary act that express the psychological. Feeling of the speaker through their utterance, such as; "thank", "congratulate", "apologize" and "welcome". Bring forward Yule (1996) explain expressive illocutionary act as types of speech act that deliver the statement including "pleasure, pain, like, dislike, thanking, apologizing, etc,".

Some of the example of expressive from the conversation above, mostly found in the barista utterances when they welcoming their customers, such as "bi, welcome", "assalamualikum". As well as when the speaker says "thank you" in the conversation, means that both customer and barista produced the expressive illocutionary act thanking.

TABLE 6. Percentage types of Illocutionary Act

\begin{tabular}{cccc}
\hline No. & Types of Illocutionary Act & $\begin{array}{c}\text { Total } \\
\text { Utterance }\end{array}$ & Percentage \\
\hline 1 & Representative & 27 & $39 \%$ \\
2 & Directives & 33 & $47 \%$ \\
3 & Expressive & 10 & $14 \%$ \\
\hline \multicolumn{4}{c}{ Total } \\
\hline
\end{tabular}

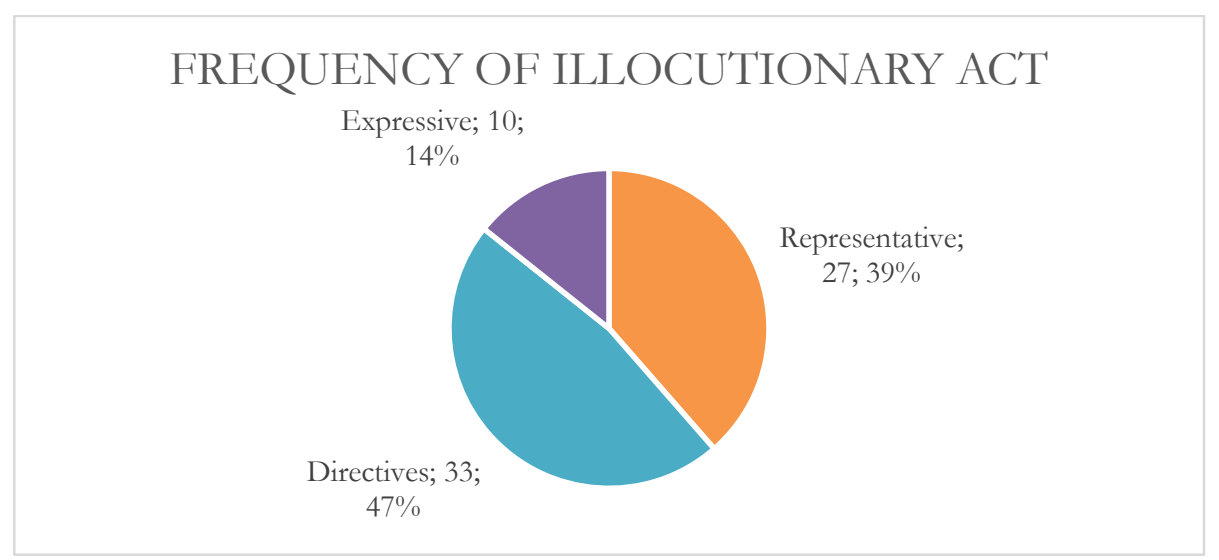

Figure 1. Frequency of Illocutionary Act 
After the calculation and put the data into chart like in the display above, the researcher got only three types of illocutionary act found in the conversation between barista and customers at Starbucks coffee shop Changi Airport Singapore. The researcher did not find others two types of illocutionary act, namely commissive and declaration in the data conversations above.

\section{CONCLUSION}

From all the types of Illocutionary act, there five classification, namely: representatives, directives, commissive, expressive, and declaration, but from all utterances data, the researcher found only three types of illocutionary act occurs. First, expressive occur in 10 utterances with percentage $15 \%$, this type of illocutionary act least occurs in both speaker (barista and the customer) to say thank or welcoming; Second types is representative occur in 27 utterances with percentage $38 \%$, this type mostly produced by both speaker barista and customers in term of giving information (inform); and the last type as the most frequently found is directives, with the percentage $47 \%$ it occurs in 33 utterances, it occurs in term of asking as well as for ordering from customers.

Communication that take place in coffee shop between the barista and customers is only three types of utterances that are encountered (representative, directive, and expressive) because in the scope of communication in coffee shop usually only needed to ordering and just give information (informing). Therefore, the two other types, declaration and commissive are not found in this study.

\section{REFERENCE}

Austin, J. L. (1975). How to Do Things with Words (Second Edi). Cambridge: Harvard University Press. Cutting, J. (2002). Pragmatics and Discourse: A Resource Book for Student. London: Routledge.

Searle, J. R. (1979). Expression and Meaning: Studies in the Theory of Speech Acts. New York: Cambridge University Press.

Simon, S., \& Cartis, D. (2015). Analysis and Classification of Directions in Written Advertisements. Procedia - Social and Behavioral Science. https://doi.org/10.1016/j.sbspro.2015.06.034

Yule, G. (1996). Pragmatics. New York: Oxford University Press.

Yule, G. (2010). The Study of Language (Fourth Edi). Edinburgh: Cambridge University Press.

Yuniati, M. (2013). Expressive Illocutionary Acts Identified in the Newly-Married Couple Drama Script. Humanis - Journal of Arts and Humanities, 2(3). Retrieved from https://ojs.unud.ac.id/index.php/sastra/article/view/5006 